Archaeological Journal

\title{
A Roman Lighthouse
}

\section{Talfourd Ely M.A., F.S.A.}

To cite this article: Talfourd Ely M.A., F.S.A. (1903) A Roman Lighthouse, Archaeological Journal, 60:1, 247-255, DOI: $10.1080 / 00665983.1903 .10852943$

To link to this article: http://dx.doi.org/10.1080/00665983.1903.10852943

$$
\text { 曲 Published online: } 16 \text { Jul } 2014 .
$$

Submit your article to this journal

LII Article views: 2

Q View related articles $\asymp$ 


\section{A ROMAN LIGHTHOUSE.}

\section{BY TALFOURD ELY, M.A., F.S.A.'}

The Greeks were fine builders, excelling in accurate workmanship as exemplified in the exquisitely fitted masonry of the Parthenon. The Romans had to provide larger edifices involving difficulties as to time and cost; hence the habitual use of concrete and the employment of the arch to bridge wide spaces.

Yet their materials, if inferior, as brick and concrete in place of stone and marble, were most carefully prepared. A proof of this is the striking permanence of Roman concrete and mortar, due in great measure to good mixing, as well as to judicious choice of ingredients. A very limited use of coal, and a corresponding limitation in the employment of iron, must have fettered the powers of the ancient architect, and still more those of the engineer.

In the various departments of physical science especially, the civilisation of the classic world undoubtedly stood far behind that of our own times; and we cannot suppose that the Greeks and Romans, even in their palmiest days, could provide against the dangers of navigation by any such series of warning beacons as now girdles our own shores.

Lighthouses of a kind, however, they certainly had, as we should know from evidence both literary and monumental, even if there were no remains of the actual buildings themselves.

Homer's ${ }^{2}$ comparison of the flash from the shield of Achilles to the gleam from the lonely mountain watchfire borne over the deep to storm-tossed sailors, can hardly be pressed into our service.

But later Greek writers, as Strabo, ${ }^{3}$ tell us of the manystoried tower so skilfully constructed for the Ptolemies

1 Read at the Monthly Meeting of the Institute on 6th May, 1903.

2 Iliad, XIX. 375.
${ }^{3}$ Section 791. See also Lucan, IX. 1004; and Lucian, Quomodo Historia sit conscribenda, 62 . 
by Sostratus of Cnidos, at Alexandria, on the island Pharos, whence it derived its name, and handed that name down to later beacons. This tower was devoted, as an inscription on it declared, to the preservation of seafarers. Its cost, eight hundred talents, may be explained partly by its size, partly by its material, white marble. Caesar, who was not given to exaggeration, pronounces it to be turris magna altitudine, mirificis operibus exstructa. ${ }^{1}$

Pliny ${ }^{2}$ describes its use, and adds that similar lights were kindled in several places, instancing Ostia and Ravenna. Strabo ${ }^{3}$ tells us it had many stories. Herodian ${ }^{4}$ compares the funeral pile of a Roman Emperor ${ }^{5}$ to lighthouses, as being constructed with stories diminishing from below, a feature common to existing beacon towers of Roman origin.

Among the omens immediately preceding the death of Tiberius, Suetonius mentions the fall of a pharos at Capreae in consequence of an earthquake. ${ }^{6}$

The Peutingeriana Tabula Itineraria contains three coloured representations of lighthouses; one (in segment IV) isolated, at the mouth of the Tiber $;^{7}$ the second (in segment VIII.) at Alexandria, a yellow building with arches, through one of which flows water, the summit being crowned by a red ball with yellow indications of flames; the third is a similar but smaller edifice, opposite Constantinople, marked "Chrisoppolis" [sic].

If literary evidence as to the subject of our enquiry be but scanty, as we must perforce confess, it may be eked out by the testimony of coins and other works of art, such as the lamp engraved in Bellori's Le antiche Luccrne (III. 12), representing a pharos with two diminishing stories above the ground floor, and a flame rising from the top.

In the collection of coins at the British Museum, there are at least four specimens illustrative of ancient light-

1 Civil War, III. 112.

2 Nat. Hist. XXXVI. 83.

3 XVII. 791.

4 IV. $2,8$.

5 Representations of the funeral pile may be seen on coins, e.g. that of
Severus. See Cohen, Description historique des monnaies, IV. 12, No. 89.

6 Tiberius, 74. This pharos seems to have been rebuilt, for it is mentioned in the Silvae of Statius, III. 5, 100.

See Dio Cassius, LX.11: Valerius, Flaccus, VII. 84: Jurenal, XII. 76. 
houses; and of these, through the courtesy of Mr. Grueber, I am enabled to exhibit casts.

One of the casts is taken from a medallion of Commodus, struck to commemorate his safe arrival in the harbour at the mouth of the Tiber; the lighthouse being depicted with three floors, each of the two upper stories containing less area than the one below. From the summit rises a large flame. ${ }^{1}$ A second cast, from a "large brass" of Severus, belongs to Abydos, and is merely a fancy sketch of Hero lighting Leander across the Hellespont. ${ }^{2}$ The remaining two casts are from denarii of Sextus Pompeius, representing the pharos of Messina, in commemoration of a naval victory. Here there is no apparent division of the tower into separate stories. Both denarii are figured in Babelon's Monnaies de la Republique Romaine. ${ }^{3}$

A relief in the Museo Torlonia (Baumeister, Denkmäler, fig. 1688) shows the beacon lighting the harbour at the mouth of the Tiber, a mass of flame issuing from the summit of a tower with several stories each of less diameter than the one beneath.

Of the actual lighthouses of antiquity the remains still left to us are naturally few and far between : perierunt. etiam ruinae.

As to the parent of all, the lofty tower raised by Sostratus to guide the course of those luxurious galleys that ministered to the pride of a Ptolemy, modern travellers are silent.

The famous harbour of a more classic age, the Piraeus, was without doubt well provided with beacons for the cornships and the triremes of Athens. An American scholar, Mr. A. C. Merriam, ${ }^{4}$ speaks indeed of three lighthouses at the Piraeus, partly relying on the testimony of certain inscriptions; but I must confess to some difficulty in following his argument. ${ }^{5}$

At Corunna, to the east of the bay of Orzan, on a rock about 120 metres high, stands a tower, known locally as Torre de Hercules, the lower part of which dates in all

1 Cohen, III. 357, No. 995.

2 Baumeister, Denkmäler, 962.

3 II. 352-3, Nos. 22 and 23.
${ }_{4}$ Telegraphing among the Ancients, $14,15$.

3 See Foucart, Bull. de Corr. Hellen, 1887,140 , who thinks onj 
probability from the times of Augustus. ${ }^{1} \quad$ This seems to have served as a beacon.

Among Caligula's mad freaks, there was one useful result of the war which he declared against Ocean, or rather the British Channel. To commemorate his imaginary victory he caused a lofty tower to be built, from which as a Pharos flames should flash forth by night to guide the course of ships." This must have been the "Tour d'Odre" (or d'Ordre) at Boulogne, an octagonal tower, about 124 feet high, rising in twelve stages, which diminished gradually from base to summit. Among English sailors it went by the name of "The Old Man." ${ }^{3}$ Of this tower, which was destroyed in 1644 , a representation is given in Montfaucon's L'antiquité expliquee, ${ }^{4}$ from a drawing made before that date.

Those who have stood upon the massive platform within the great fortress of Richborough will understand that provision may have been there made for the erection of a great beacon, which could also have served (as $\mathrm{Mr}$. Fox has remarked) for transmitting signals to Regulbium.

At Reedham, opposite Burgh Castle (Gariannonum), " the foundation of a Pharos, or watch-tower," is said to have been laid open early in the last century. ${ }^{6}$

It is to Dover, however, that we must turn for a wellknown example of a Roman lighthouse. Within the precincts of Dover Castle, in close proximity to the ancient church of St. Mary-within-the-castle (itself formed in great part of Roman materials) still stands the Roman Pharos, which Stukeley believed " the most perfect of any left."

A later historian, Mr. Puckle, considers the basement only to be of Roman work, and the octagon above to belong to Tudor times; but adds that the Pharos " has enough of the substratum of the fabric left to afford a hint of its 181.

- Suetonius, De Tita Caesarum, IV.

46. From the letters C.C.P.F. antiquarian ingenuity has evolred Caius Caligula Pharum Fecit.

3 Fuckle, The Church and Fortress of Dover Castle, 10.

4 Supplement, T. IV. plate L, 133. It is also shown in the engraving of one of the lost Cowdray pictures, that of the Departure of IIenry VIII. from Calais, published by the Society of Antiquaries.

5 Archaeological Journal, LIII. (1896), 363.

${ }_{6}^{6}$ Archaeologia, XXIII, 364.

- Itinerarium Curiosum (Second edition, 1776), Iter V. p. 129 . Plates 46-48 show the Pharos. See also Lieutenant Peck's Notes in Archaeologia, XLV. 
original form of structure. It is still a massive shell; the inner face of its walls vertical and squared, the outside showing tendency to a conical form." "Important as $D u$ brce undoubtedly was, it seems strange that it should have required two lighthouses. Yet, according to Stukeley, " on the other high cliff. opposite to this, beyond the town, has been another Pharos; some part of the bottom part of it is still left, called The Devil's Drop, from the strength of the mortar; others call it Bredonstone. Here the new constable of the castle is sworn."

Mr. Puckle too speaks of two lights, remarking that " if the lower part of the Pharos represents one, the foundation lately uncovered in excavating for the Western Redoubt probably represents the other." The materials of the latter, he adds, "are exactly like those of the eastern Pharos."

Montfaucon also alludes to this "goutte" in connection with the Tour d'Odre; a passage from which it appears that the tower of the church of St. Marywithin-the-castle had been at one time supposed to represent the Roman Pharos on the eastern cliff.

We might reasonably look for vestiges of such beacons at Reculvers, or in the Isle of Wight, or other portions of our coasts known to have been visited by the Romans, though no such general pilgrimage has been entered upon by me. A few years ago, however, I undertook to read right through the four thousand closely printed columns of the Dictionary of Greek and Roman Antiquities. There among many things never known to me and many forgotten, I came across the mention of a Roman lighthouse on the southern shore of the Dee.

Of this, as it appeared in Pennant's time, we have an interesting description in his History of the Parishes of Whiteford and Holywell (pp. 111-113), which, being accompanied by an engraving, is of great value as throwing light on the problem concerning modern restorations. It may be well to quote this description at length.

\footnotetext{
1 The Church and Fortress of Dover Castle, p. 9.

- Stukeles, op. cit. p. 130, notet.

3 Puckle, op. eit. 7. See Edward Knocker, An account of the Grand
}

Court of Sheproay, Holden on the Bredenstone Hill at Dover, 47-50. The "Ara Caesaris" or Bredenstone is represented as a rignette on p. 41 . 
"The next township to the village is in Whitford Garn. In this township is Garreg, or The Rock, the highest land in the parish; it is a large inclosed hill, the property of Sir Roger Mostyn. Part of it is a fine turf, and excellent sheep-walk; the summit, and part of the sides, rocky. From Whiteford to the top is a continual ascent. From this height the traveller may have an august foresight of the lofty tract of Snouclon, from the crooked Moel Shabog, at one end, to the towering Pen-maenmawr at the other ; of the vast promontory of Llandudno, and part of the isle of Anglesea, with the great bay of Llanddulas, forming an extensive crescent; the estuaries of the Lee and the Mersey; and to the North (at times) the isle of Man and the Cumberland Alps, the frequent presages of bad weather.

"The Romans took advantage of this elevated situation, and placed on its summit a Pharos, to conduct the navigators to and from Deva, along the difficult channel of the Seteia Portus. The building is still remaining. It is tolerably entire; its form is circular; the inner diameter twelve feet and a half; the thickness of the walls four feet four inches. The doors, or entrances, are opposite to each other; over each is a square funnel, like a chimney, which opens on the outside, about halfway up the building. On each side is a window. About four feet from the ground are three circular holes, lined with mortar, as is frequent in Roman buildings; and penetrate the whole wall, for purposes now unknown.

"W Withinside are the vestiges of a stair-case, which led to the floors, of which there appear to have been two. Along such part of the upper, which was conspicuous from the channel, are eight small square openings, cased with free-stone (the rest of the building being of rude limestone, bedded in hard mortar) and each of these were separated by wooden pannels, placed in deep grooves, the last still in a perfect state. In each of these partitions were placed the lights, which the Romans thought necessary to keep distinct, or to prevent from running into one, lest they should be mistaken by seamen for a star. Periculum in corrivatione ignium, ne sidus existimetur.

"To the building is very evidently a broad and 
raised road, pointing from the east; and near its upper end are the marks of a trench, which surrounded and gave protection to this useful edifice. It certainly had in later times been repaired, or perhaps applied to some other use, for in one part is a piece of timber which could not have been aboriginal."

In 1900, and again in 1901. I walked over to Garreg from Holywell, and carefully examined the exterior of the building, which, however, I could not enter as the door was locked.

I then had some correspondence and an interview with the owner of the property, Lord Mostyn; and in June, 1902 , by his permission I examined the interior of the tower, but found no trace of an ancient staircase. The "vestiges" seen by Pennant may have been sacrificed in restoration, or (as at present) the means of access to the upper floors may have consisted simply of a wooden ladder.

The thickness of the wall on the ground floor, at least 4 feet, was ascertained by measuring the two port holes which remain open throughout at a height of about 5 feet from the present surface of the ground. They look east and west. A third is partly blocked. They are rounded, and measure from 9 to 11 inches across. ${ }^{1}$

The height of the first floor is about 8 feet, and is marked by the slight setting back of the wall, corresponding to a similar diminution of thickness outside.

This floor has two windows looking north over the Dee, their sills being about 12 feet from the ground.

The top story has a modern wooden floor 14 feet in diameter. The battlements and great part of the wall are also modern. The three embrasures, 2 feet thick, are, however, probably original, as are certainly their outer sills of stone, each containing two diamond-shaped sockets, perhaps with a view to the division of the lights to

1 In his notes on the Roman Pharos in Dover Castle (Archaeologia, XLV. p. 333) Lieutenant Peck remarks, " with a view perbaps of drying the mass a number of airholes are carried through at regular intervals." The Rev. W. Bingley, in Excursions in North Wales, writes of a Roman fort near Carnarvon,
"Along these walls there are three parallel rows of circular holes, each nearly three inches in diameter, which pass through the entire thickness"; adding that they may have been intended "to bear the horizontal poles for resting the scaffolding upon, necessary in the building of the fabric." 
prevent its being mistaken for a star, a danger referred to by Pliny. ${ }^{1}$

These three embrasures are much smaller than the two windows of the first floor.

The building stands on the summit of Garreg Hill, and commands a splendid view over the estuary of the Dee. Its general appearance is that of a martello tower, but it is composed entirely of stones bedded in mortar. The "Jubilee" restorations comprise the crowning of the top of the building with battlements, and the filling up of the two large gaps in the lower portion, one of which is shown by Pennant. In place of the southern gap is the modern entrance closed by a door, the key of which is in Lord Mostyn's possession.

If we consider the side nearest the Dee to represent, roughly speaking, the north, there was on the north-west a doorway, now blocked up. The outside, like the interior, is divided into three stages, the wall of the upper two being slightly set back.

There is no trace of windows on the southern side. On the north there are still three at the top and two in the middle division, the more westerly of these two being over the closed doorway.

Lord Mostyn informed me that some had suggested that the tower had been a windmill; others that it had been built as a summer retreat for an abbot.

$\mathrm{He}$ himself, however, agreed with me in maintaining that it was originally a Roman lighthouse.

It seems to me unlikely that mediaeval monks would have troubled themselves to erect such a building on the top of a high hill, far from water and other necessaries, when they might have had a much more comfortable residence lower down the slopes. Again, the thickness of the wall and the want of space within are inexplicable on the theory that we are dealing with an ordinary dwelling. But such thickness of wall would be a reasonable provision to meet the great weight of iron and timber required for an effective beacon.

It is true that no Roman bricks are to be seen in the structure; they would, however, hardly be required when

1 Nat. Hist. XXXVT. 83 ; "Pericu. lum in continuatione ignium, ne sidus existimetur, quoniam e longinquo similis flammarum aspectus est." 


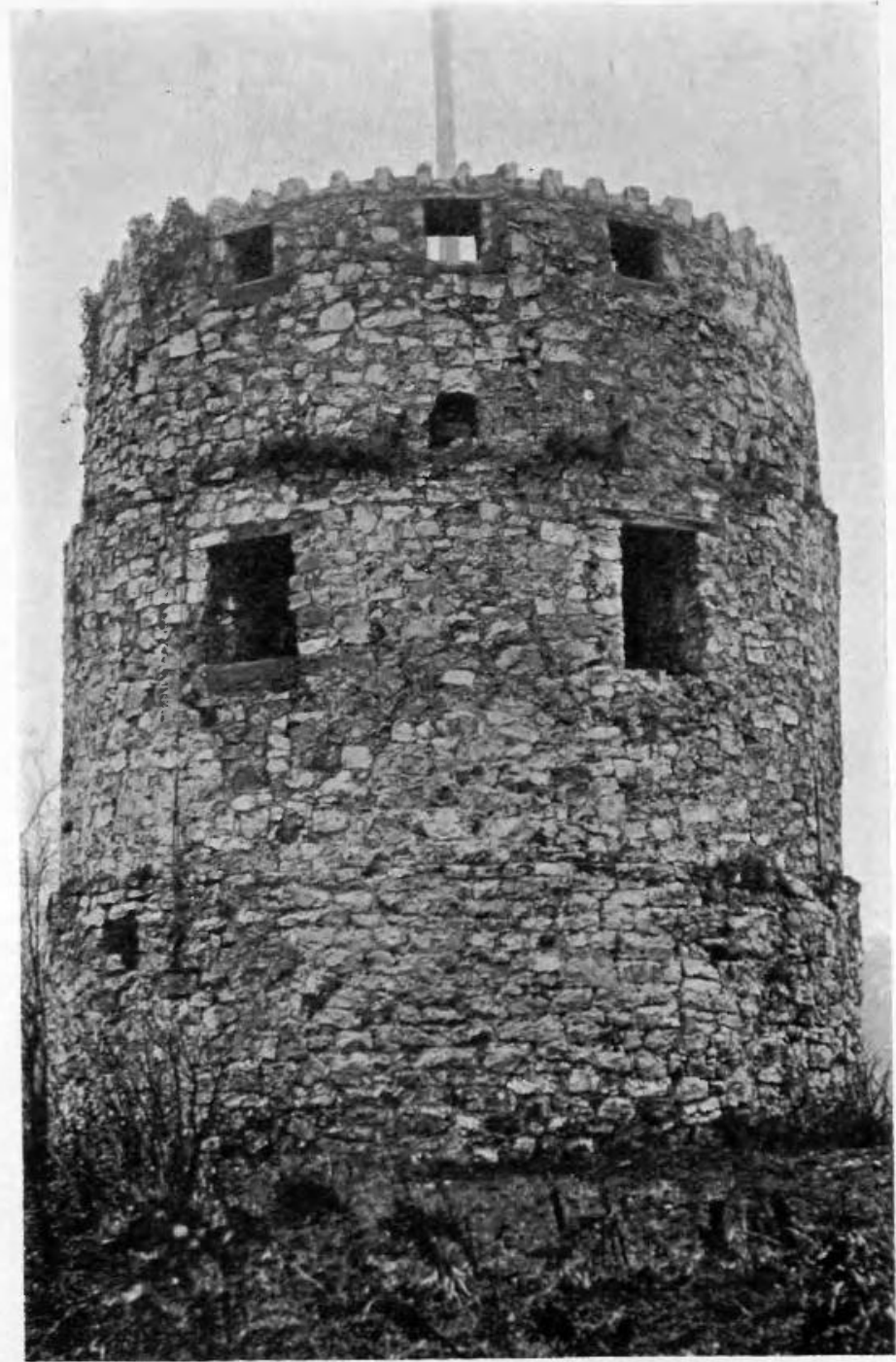

A ROMAN LIGHTIOUSE AT GARREG, ON TITE DEF. 
excellent building stone was ready to hand; and the method of construction with diminishing girth is paralleled by that of the admittedly Roman lighthouse still in existence at Dover, and the lighthouse represented on the medallion of Commodus, ${ }^{1}$ on - the Torlonia relief, and on Bellori's lamp. Another example was furnished by the Tour d'Odre. ${ }^{2}$

It is of course quite possible that in later ages a Roman beacon tower may have been utilised for a windmill or fur other purposes; but the several apertures facing the water accord well with the subdivision of the light referred to by Pliny, and I believe that on Garreg Hill we have a rare example of the survival of a genuine lighthouse dating from those early days when this country was governed by the lieutenants of Imperial Rome.

For the accompanying illustration I am indebted to Mr. Robert Newstead, curator of the Grosvenor Museum, Chester.

See abore.

2 See also Renard, Les Phares. 